\title{
SP-100 Design, Safety, and Testing
}

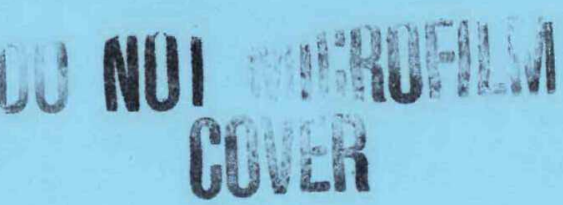

Prepared for the U.S. Department of Energy Assistant Secretary for Nuclear Energy

\section{Westinghouse \\ Wanford Company Richland, Washington}

Hanford Operations and Engineering Contractor for the

U.S. Department of Energy under Contract DE-AC06-87RL10930

Copyright License By acceptance of this article, the publisher and/or recipient acknowledges the U.S. Government's right to retain a nonexclusive, royalty-tree license in and to any copyright covering this paper.

Approved for Public Release 


\section{DISCLAIMER}

This report was prepared as an account of work sponsored by an agency of the United States Government. Neither the United States Government nor any agency Thereof, nor any of their employees, makes any warranty, express or implied, or assumes any legal liability or responsibility for the accuracy, completeness, or usefulness of any information, apparatus, product, or process disclosed, or represents that its use would not infringe privately owned rights. Reference herein to any specific commercial product, process, or service by trade name, trademark, manufacturer, or otherwise does not necessarily constitute or imply its endorsement, recommendation, or favoring by the United States Government or any agency thereof. The views and opinions of authors expressed herein do not necessarily state or reflect those of the United States Government or any agency thereof. 


\section{DISCLAIMER}

Portions of this document may be illegible in electronic image products. Images are produced from the best available original document. 


\section{DISCLAIMER}

This report was prepared as an account of work sponsored by an agency of the United States Government. Neither the United States Government nor any agency thereof, nor any of their employees, nor any of their contractors, subcontractors or their employees, makes any warranty, express or implied, or assumes any legal liability or responsibility for the accuracy, completeness, or any third party's use or the results of such use of any information, apparatus, product, or process disclosed, or represents that its use would not infringe privately owned rights. Reference herein to any specific commercial product, process, or service by trade name, trademark, manufacturer, or otherwise, does not necessarily constitute or imply its endorsement, recommendation, or favoring by the United States Government or any agency thereof or its contractors or subcontractors. The views and opinions of authors expressed herein do not necessarily state or reflect those of the United States Government or any agency thereof.

Printed in the United States of America

DISCLM-2.CHP (7-90) 


\title{
SP-100 Design, Safety, and Testing
}

\author{
G. L. Smith \\ C. M. Cox \\ M. K. Mahaffey
}

Date Published

July 1990

To be presented at American Nuclear Society

Topical Meeting on the

Safety, Status and Future of

Non-commercial Reactors

and Irradiation Facilities

Boise, Idaho

September 30-October 4, 1990

Prepared for the U.S. Department of Energy Assistant Secretary for Nuclear Energy

\section{(2) \\ Westinghouse \\ Hanford Company Richland, Washington 99352}

Hanford Operations and Engineering Contractor for the

U.S. Department of Energy under Contract DE-AC06-87RL10930

Copyright License By accoptance of this article, the publisher and/or recipient acknowledges the U.S. Government's night to retain a nonexclusive, royatty free license in and to any copyright covering this paper. 


\author{
Cari M. Cox, Michael M. Mahaffey, and Gary L. Smith \\ Westinghouse Hanford Company \\ Post Office Box 1970 \\ Richland, Washington 99352
}

(509) 376-3749

\section{ABSTRACT}

The SP-100 Program is developing a nuclear reactor power system that can enhance and/or enable future civilian and military space missions. The program is directed to develop space reactor technology to provide electrical power in the range of tens to hundreds of kilowatts. The major nuclear assembly test is to be conducted at the Hanford Site near Richland, Washington, and is designed to validate the performance of the 2.4-MWt nuclear and heat transport assembly.

\section{BACKGROUND ON NATIONAL EFFORTS}

The SP-100 Program is jointly sponsored by the U.S. Department of Energy (DOE), the National Aeronautics and Space Administration, and the Department of Defense for the purpose of developing a nuclear reactor power system that can enhance and/or enable future civilian and military space missions. The program is directed to develop space reactor technology to provide electrical power in the range of tens to hundreds of kilowatts.

The DOE is responsible for development and ground testing of hardware usable for future space missions. This responsibility encompasses generic flight system (GFS) design, ground engineering subsystems design, engineering development, and ground testing to validate the readiness of the system technology for dedicated flight use. The GFS is a $100-\mathrm{kW}$ electric space reactor power system point designed by General Electric that provides the basis for Ground Engineering System (GES) Test Site activities. This design is adapted as necessary for ground testing.

The major assembly-level nuclear test to be conducted in the SP-100 GES Program is referred to as the Nuclear Assembly Test (NAT). The NAT is designed to validate the performance of the nuclear assembly by up to 2 years of reactor operation conducted in a vacuum chamber to simulate space conditions within a reactor containment structure. The test article will include the SP-100 reactor, instrumentation and control, primary heat transport loop, and radiation shield subsystems prototypical of the technology required for the flight system design.

\section{ASSEMBLY TEST PROGRAM}

The major goals that must be accomplished to allow decisions to be made to use SP-100 technology and systems in space are (1) comple- tion of a GFS design that is responsive to user needs, and (2) successful development, assembly, and ground demonstration testing (in a simulated space environment) of a fully operational reactor and associated components and hardware assemblies representative of a compact electric space reactor power system. The design and component development work is presenty under way to meet these goals. This paper will discuss the large nuclear assembly testing that is planned.

In conjunction with the life test program, major assemblies of the design will be fabricated and tested to demonstrate the design's ability to meet performance specifications and interface requirements. The assemblies to be tested are a NAT at the Hanford Site, Washington, and a Converter Pump Assembly Test (CPAT) at Valley Forge, Pennsylvania. The NAT includes a flight-like reactor assembly, a reactor instrumentation and control assembly, and a shield assembly. The NAT will be conducted in a containment building with a shielded thermal. vacuum vessel to simulate space conditions. The CPAT will include an electrical resistive heat source to generate the appropriate fraction of the full heat load, a heat transport assembly including a thermoelectricelectromagnetic (TEM) pump, and a thermoelectric converter assembly. The CPAT will be conducted in a thermal-vacuum vessel to simulate space conditions.

\section{GENERAL PLANT DESCRIPTION}

The SP-100 GES Test Site is a DOE facility located on the Hanford Site near Richland, Washington. The facility will provide for the safe and reliable operation of a liquid metal-cooled, fast flux nuclear reactor in an environment closely simulating the vacuum and temperature conditions of space operations. The facility will provide the reactor containment, the associated heat transport, vacuum, plant protection, support (e.g., electric power and ventilation), and security systems necessary to support the test program for the SP-100 GES NAT (see Figure 1). Figure 2 is a simplified view of the NAT and the nuclear support systems.

\section{A. Nuclear Assembly}

The reactor, flight shield, and controls and instrumentation used in the ground test will be prototypic of the technology required of orbiting GFSs. Characteristics of the Nuclear Assembly are listed on the next page. 


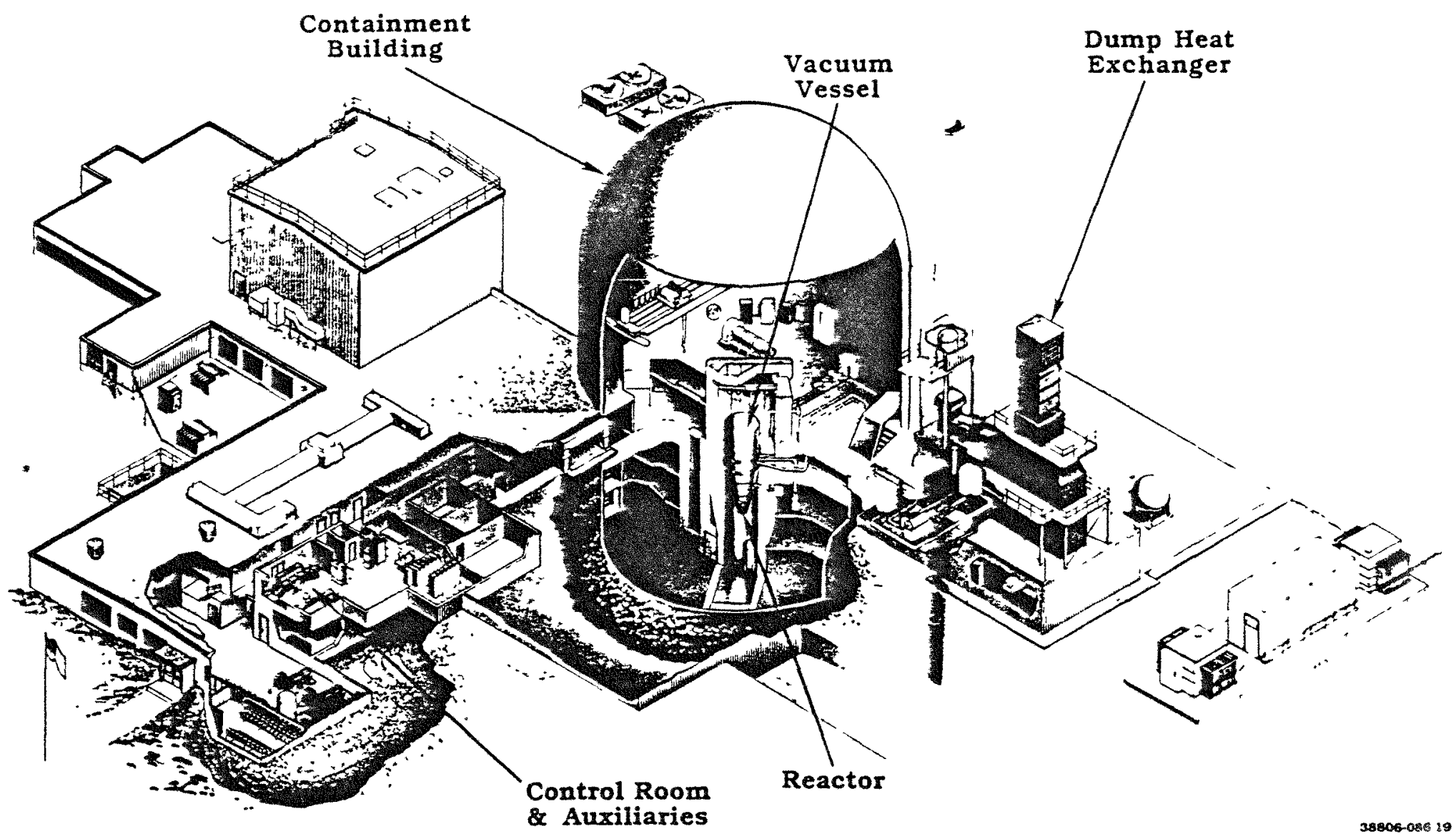

Fig. 1. SP-100 Ground Engineering System Preliminary Equipment Arrangement.

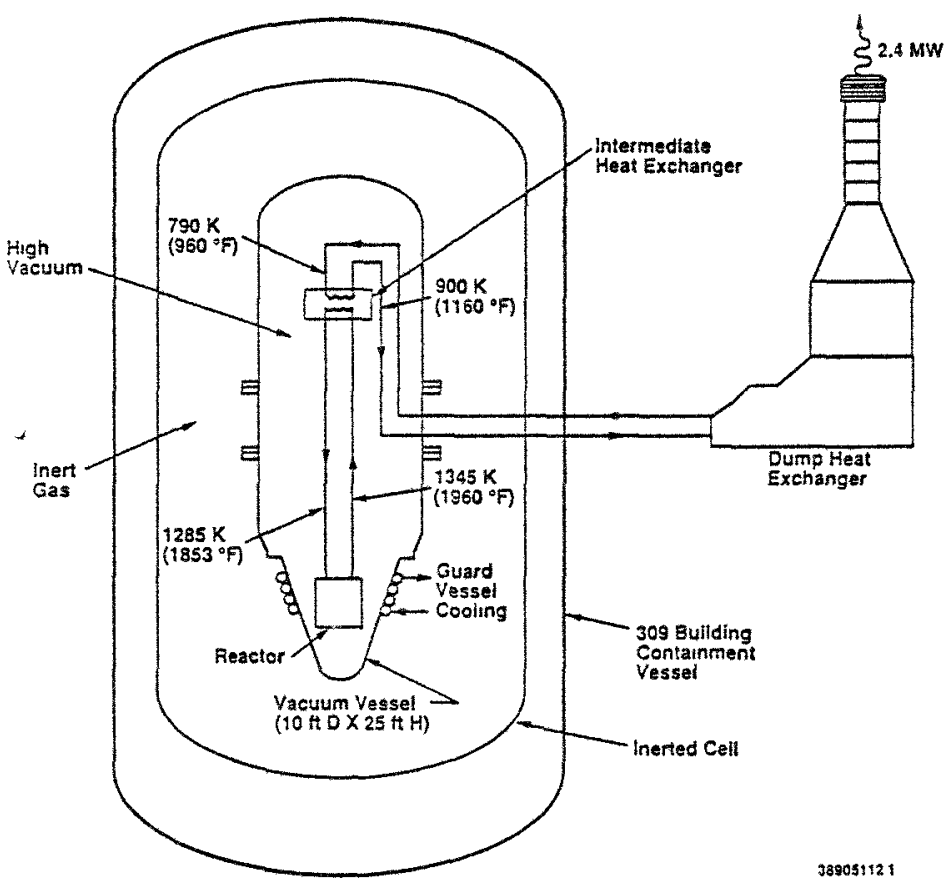

Fig. 2. SP-100 Ground Engineering System Nuclear Assembly Test.
Nuclear Assembly Nominal Design Characteristics

Thermal Power (MW)
Outlet Temperature $\left[\mathrm{K}\left({ }^{\circ} \mathrm{F}\right)\right]$
Inlet Temperature $\left[\mathrm{K}\left({ }^{\circ} \mathrm{F}\right)\right]$
Coolant
Flow Rate $[\mathrm{kg} / \mathrm{s}(\mathrm{lb} / \mathrm{h})]$
Fuel
Fuel Enrichment
Number of Fuel Assemblies
Mass of ${ }^{235} \mathrm{U}[\mathrm{kg}(\mathrm{lbm})]$
Cladding
Reactor Structural Material
Bayonet Cooling Tubes
Reflector Control Elements (12)
Safety Rods (3)
Reactor Core Diameter [cm (in.)]
Reactor Core Length [cm (in.)]
Prototypic Flight Shield

$2.4 \pm 0.1$

$1345(1961)$

$1285(1853)$

Lithium-7

$48(381,000)$

Uranium Nitride

$89 \% / 97 \%$

30

$170(375)$

$\mathrm{Nb}-1 \mathrm{Zr}$ Alloy

$\mathrm{Nb}-1 \mathrm{Zr}$ Alloy

42

Beryilium Oxide

Boron Carbide

$34.5(13.6)$

$39.4(15.5)$

Lithium Hydride, Beryllium, Tungsten

The reactor is a fast-neutron-spectrum design with sealed uranium nitride fuel pins contained in a single vessel with liquid lithium circulated as the coolant. The reactor core is about $35 \mathrm{~cm}$ (13.6 in.) in diameter by $40 \mathrm{~cm}$ (15.5 in.) high. Niobium $1 \%$ zirconium $(\mathrm{Nb}-1 \mathrm{Zr})$ refractory metal is used for the reactor fuel cladding and structural material. The reactor is nominally rated at $2.4 \mathrm{MWt}$ and delivers its thermal energy to liquid lithium at $1345 \mathrm{~K}\left(1961^{\circ} \mathrm{F}\right)$. The core structure is a honeycomb forming an array of hexagonal ducts, each containing 37 pins (see Figure 3). 


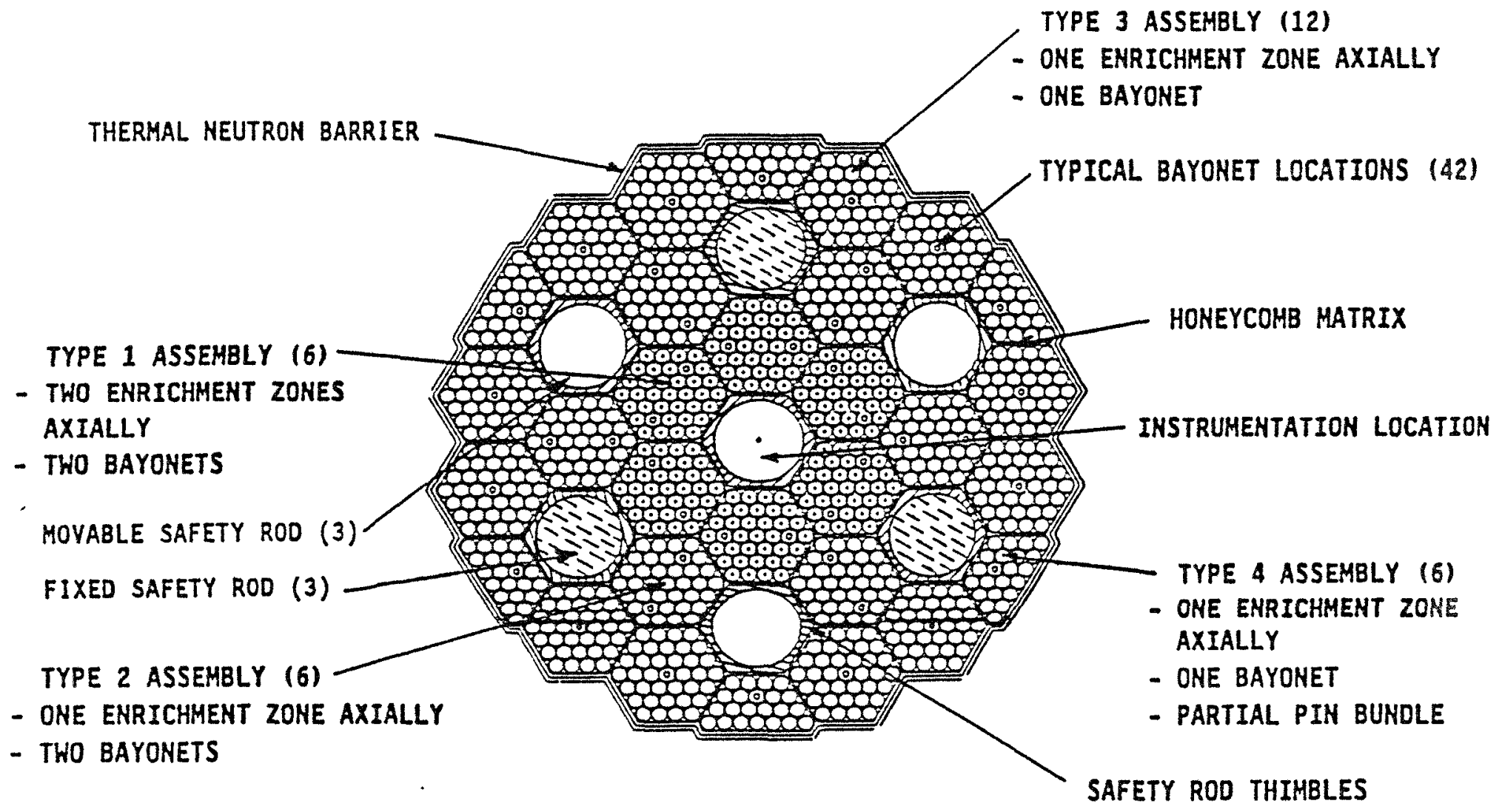

Fig. 3. Core Map for the Nuclear Assembly Test.

Seven of the ducts in the core honeycomb structure contain hexagonal thimbles with a cylindrical cavity. The in-core safety rods have $\mathrm{a} \mathrm{B}_{4} \mathrm{C}$ absorber section for shutdown and a $\mathrm{BeO}$ follower that resides in the core region when the reactor is critical. In the NAT, three of the cavities will contain safety rods. The other four cavities will contain rods that are fixed in the reactor-critical position (BeO in the core region). The central rod will also contain the NAT neutron source and core temperature instrumentation. The NAT safety rods will be used exclusively for shutdown. The reactor will be controlled by 12 hinged radial reflector elements of $\mathrm{BeO}$ located outside of the reactor vessel. Both rods and reflectors will have scram capability and both will be actuated by any trip signal from the Reactor Protection System (RPS).

The Primary Heat Transport System (PHTS) transfers the thermal energy generated in the reactor to the Secondary Heat Transport System (SHTS) (see Figure 4). The PHTS consists of a lithium loop that connects to the outlet plenum of the reactor. The lithium flows to heat transport pipes to a ring header, to an expansion tank, through an electromagnetıc (EM) pump, through the tube side of an Intermediate Heat Exchanger (IFX), to an electrical heater, and finally to the inlet piping of the reactor. The primary loop contains an electric heater to provide heat input for hot functional testing and isothermal physics testing without reactor heating. The PHTS loop is located completely inside the vacuum vessel; however, the EM pump stator is located external to the vacuum vessel. The EM pump duct is in a thimble that forms an extension of the vacuum vessel. The nominal reactor inlet temperature is $1289 \mathrm{~K}\left(1861^{\circ} \mathrm{F}\right)$ with a nominal outlet temperature of $1345 \mathrm{~K}\left(1961^{\circ} \mathrm{F}\right)$.

\section{B. Vacuum Vessel}

The reactor, the Flight Shield, the lower and upper facility shields, and the PHTS will be housed in a vacuum vessel that simulates the space environment (see Figure 5). The vacuum vessel will be a segmented right-circular cylinder about $3.0 \mathrm{~m}(10 \mathrm{ft})$ in diameter with

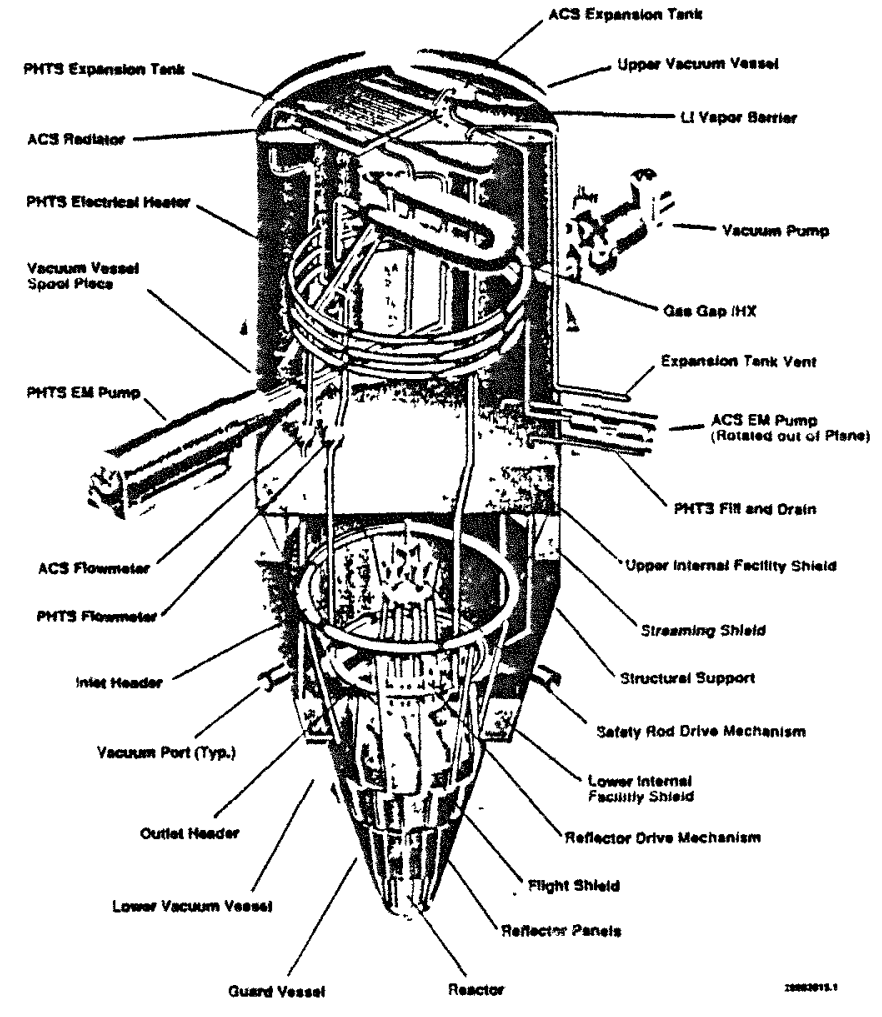

Fig. 4. SP-100 Nuclear Test Assembly.

an overall length of $7.6 \mathrm{~m}(25 \mathrm{ft})$. The vacuum vessel will be fabricated from stainless steel in accordance with the American Society of Mechanical Engineers (ASME) Boiler and Pressure Vessel Code. The vacuum vessel will be supported at its midsection with an interfacing structure to the containment building concrete structures. The vessel will form a vacuum boundary that will allow evacuation to a high vacuum level. This vacuum level not only simulates space environment 


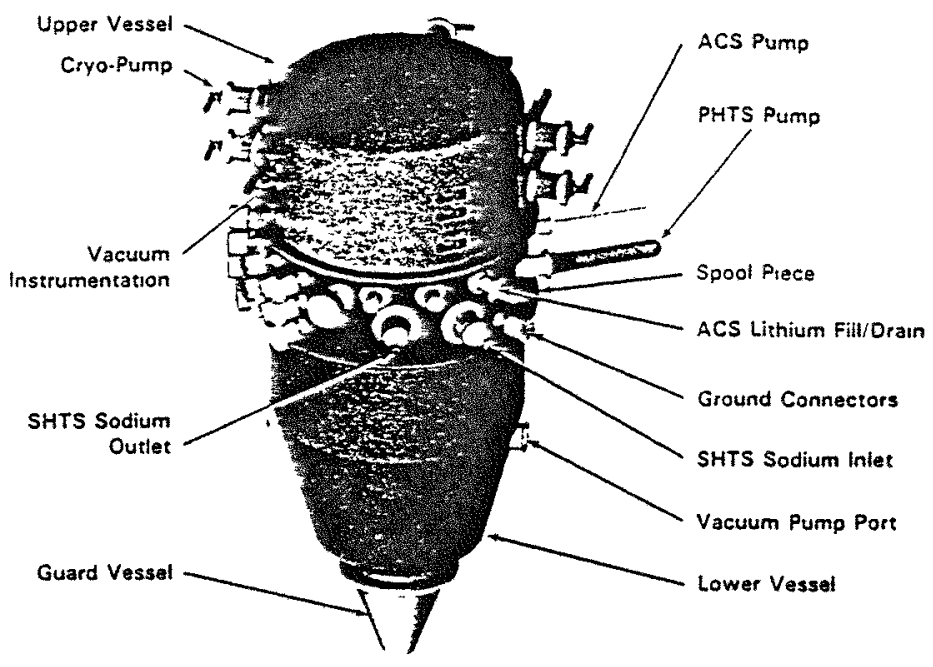

19902016 2

Fig. 5. Vacuum Vessel.

but also precludes the reaction of atmospheric and other gases with the refractory materials of the Test Assembly. The vacuum vessel will also be temperature controlled to provide a heat sink for radiative heat rejection from the Test Assembly.

\section{Vacuum System}

The Vacuum System will achieve the high vacuum level inside the vacuum vessel by a two-stage pumping system. The rough vacuum pumping package consists of mechanical pumps, which will reduce system pressure from one atmosphere ( 760 Torr) down to $10^{-3}$ Torr. The roughing package also contains cryostats to prevent oil back-streaming from the pumps to the vacuum vessel. The roughing package can be isolated from the vacuum vessel by separate isolation valves. The next pumping stage, rough to high vacuum, is achieved by turbomolecular pumps. This pumping package will reduce the vacuum vessel pressure from $10^{-3}$ Torr to $10^{-5}$ Torr (total pressure, including helium and argon). The turbomolecular pumps are connected to the vacuum vessel and are individually isolated by vacuum valves.

Lithium with reduced ${ }^{6} \mathrm{Li}$ concentrations will be used as the PHTS coolant to reduce tritium production. The majority of the tritium produced by the neutron bombardment of ${ }^{6} \mathrm{Li}$ and ${ }^{7} \mathrm{Li}$ will permeate through the PHTS pressure boundaries to the Vacuum System. Another significant source of tritium production will be neutron activation of $\mathrm{LiH}$ in the Flight Shield (retained in Flight Shield stainless steel structure), of $\mathrm{B}_{4} \mathrm{C}$ in the safety rods, and $\mathrm{BeO}$ in the reflectors and subsequent permeation of their physical pressure boundaries. The tritium that permeates to the vacuum vessel will be continuously pumped by the high-vacuum pumps and passed to the containment exhaust system where it will be monitored.

The Vacuum Vessel Inert Gas Purge System provides for safe shutdown for accidents that result from a leak in the vacuum environment surrounding the Nuclear Assembly. The $\mathrm{Nb}-1 \mathrm{Zr}$ refractory metal alloy used in the fabrication of the reactor, PHTS, and Auxiliary Coolant System (ACS) can be structurally degraded by low concentrations of oxygen and other reactive gases in air. The second function of the Vacuum Vessel Inert Gas Purge System is to repressurize the PHTS and reactor vessel in the event of a lithium leak to prevent lithium boiling at high temperatures and subatmospheric pressures.

\section{Containment Structure}

The existing containment vessel is an all-steel, cylindrical vessel $24.4 \mathrm{~m}(80 \mathrm{ft})$ in diameter and $36.9 \mathrm{~m}(121 \mathrm{ft})$ high, extending $22.9 \mathrm{~m}$ (75 ft) above grade. The containment vessel was designed, constructed, and tested in conformance with the ASME Boiler and Pressure Vessel Code, Section VIII, Division 1. 'The bottom of the vessel is $14 \mathrm{~m}$ ( $16 \mathrm{ft}$ ) below grade and is supported on a reinforced concrete pad. The internal design pressure of the vessel is $103 \mathrm{kPa}$ (15 psig), and the design maximum external pressure is $3.4 \mathrm{kPa}(0.50 \mathrm{psig})$.

\section{E. Secondary Heat Transport System}

The SHTS provides for the operational rejection of the reactor heat to ambient air using sodium as the heat-transfer coolant. The reactor heat is transferred from the PHTS into the stainless-steel SHTS through the IHX located inside the vacuum vessel. Heat is rejected to the atmosphere by a sodium-to-air Dump Heat Exchanger (DHX).

The SHTS loop consists of the shell side of the IHX, two EM pumps, a flow meter, miscellaneous valves and connecting pipes, and a forced-air DHX. Expansion and contraction of the sodium over the operating temperature range is accommodated by an expansion tank with an argon-cover gas system.

\section{F. Residual Heat Removal Systems}

Heat Transport Systems Path--The PHTS and SHTS are designed to remove reactor heat for all normal and off-normal events. Primary EM pump coastdown is not required to satisfy reactor safety limits. To protect against a complete loss of flow in the event of a loss of electrical power, the configuration of the PHTS and SHTS has been arranged to provide for natural-convective cooling for reactor residual-heat removal. Cooling for the off-normal events that seriously impair the ability of the PHTS to transfer the reactor heat to the ultimate heat sink (e.g., a failure of the PHTS boundary, failure of the SHTS boundary, or failure of the $\mathrm{DHX}$ ) is provided by the ACS.

The ACS provides an independent, redundant decay heat-removal path for the test reactor. The core incorporates 42 bayonet-configured, heat-absorbing tubes interspersed among the fuel pins. These in-core bayonet tubes are connected to an auxiliary coolant loop with lithium as the cooling medium. The auxiliary cooling loop transports decay heat by forced circulation to a radiator panel inside the vacuum vessel. The profile of the ACS components also promotes natural convective flow in the loop. The panel radiates decay heat to the cooled vacuum vessel wall, and the secondary loop of the ACS located outside the vacuum vessel transports the decay heat from the vacuum vessel wall to the ultimate heat sink. The path is independent of the main coolant loop.

\section{DESIGN AND SAFETY APPROACH}

The design, testing, and operation of the SP-100 Test Site are under the regulations and requirements of the DOE promulgated in the DOE Orders. The mandatory Environmental Safety and Health standards identified in DOE Order $5480.4^{2,3}$ are as follows:

\section{Mandatory Policy Requirements for New Construction}

- Institute of Electrical and Electronic Engineers (IEEE) 279-1971 ${ }^{4}$

- ASME Boiler and Pressure Vessel Code 
- IEEE 308-1980 for Class $1 E^{5}$

- IEEE 603-1980, Standards for Safety Systems ${ }^{6}$

Non-Mandatory--Good Practice Guidance

- 10 CFR $50^{7}$

- 10 CFR $100^{8}$

- Other IEEE Standards

- ANS Standards.

The above mandatory standards are being applied to the SP-100 NAT design and operation. The non-mandatory standards are implemented in the application of the 10 CFR 50 general (principal) design criteria, which are modified as appropriate for liquid metal reactor systems. Siting and seismic requirements of 10 CFR 100 are being applied to the design and analysis. Standards of IEEE and ANS, as well as U.S. Nuclear Regulatory Commission (NRC) Regulatory Guides, are being utilized to provide guidance to the subsystem designers.

An Environmental Assessment was submitted in December 1988. After reviews and hearings, a finding of no significant impact (FONSI) was published in the Federal Register in September 1989.

The Preliminary Safety Analysis Report (PSAR) was issued in July 1989 and submitted to the DOE for review in response to DOE Order 5480.6. ${ }^{9}$ The PSAR was developed consistent with the requirements of the NRC Regulatory Guide 1.70, Standard Format and Content for Safety Analysis Reports. ${ }^{10}$ The PSAR was independently reviewed by a DOE team to ensure that the proposed NAT met the requirements of the DOE Orders and could be performed with adequate safety and protection of the environment. The Independent Review Team issued a Safety Evaluation Report (SER) in July 1990. The SER and PSAR will be submitted to the Assistant Secretary for Nuclear Energy for consideration for approval of construction. Current planning is for approval of construction in October 1990.

\section{TEST FACILITY OPERATIONS}

\section{A. Facility Qualification Testing Program}

The SP-100 GES will be located in the 309 Building, an existing facility, which will be modified to meet DOE reactor operation criteria. A rigorous facility qualification-testing program will be conducted using written procedures, which will be developed after modification but before installation of the SP-100 GES reactor. The facility qualification program will encompass testing of both components and systems.

\section{B. Reactor Installation and Testing}

After facility qualification testing, the reactor will arrive onsite and be fueled in the 309 Building containment structure. The vacuum vessel will be closed and support system connections completed. An Integrated Leak Rate Test (ILRT) will be performed on the containment vessel before reactor testing. Startup testing will include the following:

- Lithium Fill of PHTS

- Sodium Fill of SHTS

- Fill of Lower Vacuum Vessel Cold-Wall Loop

- Vacuum Vessel Bakeout

- Natural Circulation Performance

- Testing of Residual Heat-Removal System

- Reactor Control and Safety Systems.
Reactor startup testing will be performed by qualified reactor operators with technical direction provided by test-engineering and systems-contractor personnel. All testing will be conducted using written procedures, which will be developed during the definitive design. Potential environmental releases during this phase of the life cycle for this project are addressed in the Environmental Assessment documentation and will not have a significant effect on the environment.

\section{Nuclear Assembly Test Program}

When the reactor installation and initial testing have been success. fully completed, the reactor will be operated for at least 3 months and up to 2 years at full-rated power levels for performance testing. This testing period will include startup, shutdown, and transient testing as described below.

The SP-100 GES NAT is being conducted to validate the SP-100 GFS and the associated analytical methods. These tests will be preceded by the Initial Test Program, which will confirm safety aspects of the test article.

The GFS testing is intended to verify that the test article operates as designed during normal and offnormal GFS events. A single Test Controller will have operating modes that will be manually selected by the reactor operator. This controller will provide control commands to the Nuclear Assembly and SHTS. The Test Controller will operate in three distinct modes. These modes are described below.

- Manual Mode--This mode is used to maneuver the Nuclear Assembly and SHTS manually over the expected operating range. The reactor operator manually adjusts the controller set points to achieve the desired operating condition.

- Permissive Mode--This mode is the first step to verifying automatic Flight Controller operation. In this mode of opera. tion, the controller will indicate to the operator the actions it would perform to accomplish a requested maneuver, but no automatic actions are taken. If the operator, after reviewing the controller's programmed actions, agrees with the actions, then the actions can be initiated simply by pushing the permissive button.

- Automatic Mode--This is the true Flight Controller automatic mode. In this mode, all actions are taken automatically, although there are provisions for operator override in the event of abnormal controller operation. This mode is the final demonstration that the Flight Controller is functioning as designed.

Each GFS performance test will be done twice, first in the permissive mode and then in the automatic mode.

1. Reactor Thaw with Reactor Power. The objective of this test is to conduct a thaw of the GFS reactor system using nuclear heat under simulated space conditions. Before conducting this test, the PHTS and ACS lithium will be drained to the vicinity of the reactor inlet nozzles, and then the coolant will be allowed to freeze.

2. Post-Thaw Low Flow Startup. The objectives of this test are to demonstrate that the Flight Controller is stable and that it meets requirements during the GFS low-flow startup induced power transient. In the GFS, a power transient is caused by much colder lithium entering the reactor upon TEM pump startup following thaw. This test will subject the NAT reactor to a cold lithium coolant injection transient by use of the PHTS EM pump to simulate the TEM pump startup. 
3. Generic Flight System Startup. This test simulates the GFS initial startup after flow startup following thaw. The reactor an 1 PHTS are at about $925 \mathrm{~K}\left(1205^{\circ} \mathrm{F}\right)$ and $3 \%$ flow, with the SHTS configured to simulate the GFS secondary heat sink before significant GFS secondary flow. The objective is to demonstrate acceptable Flight Controller performance for the required flight system initial startup operations.

4. Generic Flight System Scram and Restart The objective of this test is to demonstrate Flight Controller response to flight system load demand cycles, proper controller operation, and stability.

* This test will be accomplished by first establishing a steady-state condition at $100 \%$ core thermal power via the Flight Controller. The reactor will then be scrammed by the operator. The PHTS EM pump will be controlled to simulate the GFS TEM pumps. The SHTS will be controlled to produce reactor inlet temperature variations, which are representative of the GFS heat sink. The Flight Controller will place the Test Article in hot shutdown condition.

After steady-state is achieved in hot shutdown, the Flight Controller will take the reactor critical and increase load demand to the standby power state. This test is complete upon receipt of a permissive signal from the Fight Controller allowing power to be increased above the standby power state. Increase to full power will be part of the GFS Load Demand Cycle Simulation.

5. Generic Flight System Load Demand Cycles. The objective of this test is to demonstrate that the Flight Controller can acceptably control reactor power during maneuvering from full power to standby power and back to full power on command of the ground control system controller.

6. Autonomous Full Power Operation. The objective of this test is to demonstrate Nuclear Assembly response to 12 weeks of autonomous operation at $100 \%$ Core Thermal Power. The first 11 weeks of operation will be at conditions simulating GFS end-ofmission (EOM) conditions with 12 out of 12 loops operating. The last week of this full power run will simulate GFS EOM conditions with 11 out of 12 loops operating.

7. Follow-on Test Capabilities. It is anticipated that following the SP-100 GES test program the reactor building will be decontaminated for use for other programs. The safety refurbishments and upgrades performed as part of the SP-100 testing will provide an ideal test site for follow-on small reactor test programs. The upgraded containment, installed Class $1 E$ power systems, and the infrastructure associated with design, construction, analysis, and safe operation of small reactor assemblies will provide an ideal environment for safe and "cost-effective implementation of funure missions.

\section{SUMMARY}

The SP-100 Program is developing a nuclear reactor power system that can enhance and/or enable future civilian and military space missions, including possible manned Lunar bases and Mars missions. A major goal that must be accomplished to allow decisions to be made to use SP-100 technology in space is the successful development, assembly, and ground demonstration testing, in a simulated space environment of a fully operational reactor and associated components representative of a compact electric space reactor power system.
An important contribution to this goal will be the successful design and operation of the NAT at the Hanford Site, near Richland, Washington, which is designed to validate the performance of the 2.4-MWt nuclear and heat transport assembly. Test Site design is progressing to provide a test facility that will allow the safe and efficient operation of the NAT. An Environmental Assessment and PSAR. have been prepared in response to the regulations and requirements of DOE Orders.

When the reactor installation and initial testing have been success fully completed, the reactor and heat transport system will be operated for at least 3 months and up to 2 years at full-rated power levels for performance testing and demonstration. This testing period will include startup, shutdown, and transient testing.

The safety refurbishments and upgrades performed as part of the SP-100 testing will provide an ideal test site for follow-on small reactor test programs. The upgraded containment, installed Class $1 E$ power systems, and the infrastructure associated with design, construction, analysis, and safe operation of small reactor assemblies will provide an ideal environment for safe and cost-effective implementation of furure missions.

\section{REFERENCES}

1. ASME Boiler and Pressure Vessel Code, Section VIII, Division 1, "Pressure Vessel," 1986 Edition with Addenda through 1987, American Society of Mechanical Engineers, New York, New York.

2. DOE Order 5480.4 , Environmental Protection, Safety and Healsh Protection Standards, U.S. Department of Energy, Washington, D.C., 1984.

3. ASME Boiler and Pressure Vessel Code, Section III, Division 1, Subsection NE, "Class MC Components," 1986 Edition with Addenda through 1987, American Society of Mechanical Engineers, New York, New York.

4. IEEE Std 279, Criteria for Protection Systems for Nuclear Power Generating Stations, 1971.

5. IEEE Std 308, Criteria for Class 1E Power Systems for Nuclear Power Generating Stations, 1980.

6. IEEE Std 603, Criteria for Safety Systems for Nuclear Power Generating Stations.

7. Code of Federal Regulations, Title 10, Part 50, "Domestic Licensing of Production and Utilization Facilities."

8. Code of Federal Regulations, Title 10, Part 100, "Reactor Core Criteria."

9. DOE Order 5480.6, Safety of Department of Energy-Owned Nuclear Reactors, U.S. Department of Energy, Washington, D.C., 1986.

10. Regulatory Guide 1.70, Standard Format and Content for Safety Analysis Reports, U.S. Nuclear Regulatory Commission. 
WHC-SA-0817-FP

Revision 1

DISTRIBUTION

Number of Copies

ONSITE

3

U.S. Department of Energy-

Richland Operations Office

O. A. Farabee A6-55

R. G. Hastings A6-55

C. R. Richins

A6-55

48

Westinghouse Hanford Company

C. M. $\operatorname{Cox}(3) \quad$ B3-65

M. K. Mahaffey (2) L4-73

G. L. Smith (40) L4-75

Publications Services (3) L8-07

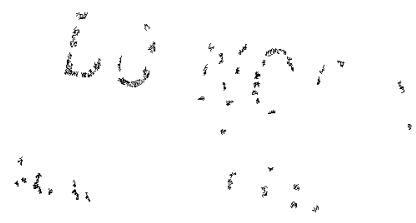

Distr-1 